NASA Technical Memorandum 83689

\title{
Tandem Fan Applications in Advanced STOVL Fighter Configurations
}

Charles L. Zola

Lewis Research Center

Cleveland, Ohio

and

Samuel B. Wilson III and Megan A. Eskey

Ames Research Center

Moffett Field, California

Prepared for the

Twentieth Joint Propulsion Conference

cosponsored by the AIAA, SAE, and ASME

Cincinnati, Ohio, June 11-13, 1984

\section{NASA}


TANDEM FAN APPLICATIONS IN ADVANCEO STOVL FIGHTER CONFIGURATIONS

By

Charles L. Zola

National Aeronautics and Space Administration
Lewls Research Center
21000 Brookpark Road
Cleveland, OH 44135

Samuel B. Wtlson, III and Megan A. Eskey

National Aeronautics and Space Administration

Ames Research Center

Moffett Fleld, CA 94035

\section{ABSTRACT}

The serles/parallel tandem fan engine is evaluated for application in advanced STOVL supersonic fighter alrcraft. Options in engine cycle parameters and design of the front fan flow diverter are examined for their effects on engine weight, dimensions, and other factors in integration of the engine with the aircraft. Operation of the engine in high-bypass flow mode during cruise and loiter flight is considered as a means of minimizing fuel consumption. Engine thrust augmentation by burning in the front fan exhaust is discussed. Achlevement of very short takeoff with vectored thrust is brlefly reviewed for tandem fan engine conflgurations with vectorable front fan nozzles. Examples are given of two alrcraft configuration planforms, a deltacanard, and a forward. swept wing, to 111 ustrate the major features, design considerations, and potential performance of the tandem fan installation in each. Full reallzation of the advantages of tandem fan propulston are found to depend on careful selection of the afrcraft configuration, since integration requirements can strongly influence the engine performance.

\section{NOMENCLATURE}

$\begin{array}{ll}\text { A/B } & \text { afterburning } \\ \text { BPR } & \text { bypass ratio } \\ \text { F } & \text { thrust } \\ \text { FPR } & \text { fan pressure ratio } \\ M & \text { Mach number } \\ N & \text { shaft rotational speed, relative } \\ N / \sqrt{\theta} & \text { corrected shaft speed, relative } \\ \text { OPR } & \text { englne cycle overall pressure ratio } \\ \text { PR } & \text { pressure ratio } \\ \text { R } & \text { degree Rankine } \\ \text { SPTF } & \text { serles/parallel tandem fan } \\ \text { STO } & \text { short takeoff } \\ \text { TSFC } & \text { thrust specific fuel consumption, } \\ & \text { lb/hr/lb } \\ \text { VL } & \text { vertical landing } \\ W & \text { weight, ib } \\ \text { Wa } & \text { engine alrflow, ib/sec } \\ \text { WG } & \text { alrcraft gross weight, ib }\end{array}$

\section{INTROOUCTION}

The next generation fighter (ATF, STOL Fighter, etc.) must takeoff and land with as large a payload as posstble even if the ground run is restricted (e.g. . bomb damage or short decks) and so will probably require that this additional capablitity be incorporated in the alrcraft design. Most of the technology issues in achleving this $k$ ind of performance have been addressed in studies of supersonic fighter alrcraft with V/STOL capability. $2-4$

Recent studies 5 see an important (and more near term) milltary role for supersonic STOVL fighter aircraft. This aircraft is designed to perform a short takeoff (STO) instead of the more demanding vertical takeoff of earlier concepts studies. The vertical landing (VL) of the atrcraft takes place at reduced gross weight and therefore requires less thrust from the propulston system. Vertical takeoff ability may still be retained in the alrcraft, but at an off-loaded lower gross weight condition.

This paper discusses the serles/parallel flow tandem fan (SPTF) engine $6-7$ as a possible candidate propulsion system for advanced STOVL supersonic fighter alrcraft. In the tandem fan engine concept the fan stages are phystcally separated to create front and rear fan sections, followed by the core, which drives them. The engine in then capable of operating in elther of two modes, "series" or "parallel." In the series mode, the front fan flow passes directly through to the rear fan and, with some of the flow bypassed, enters the core. Therefore, in serles mode the engine acts as a "conventional" mixedflow turbofan, except for the spacing between the front and rear fan sections. In parallel flow mode, however, all of the front fan flow is diverted (bypassing the engine) to an exhaust nozzle located near the front fan exit. At the same time, an auxlliary intake provides afrflow to the rear fan. The overall bypass ratio of the parallel mode is significantly greater than that of the serles mode.

The dual-mode, convertible bypass, operation of the SPTF makes it an attractive propulsion system for supersonic advanced STOVL fighters in vertical landing due to the large thrust at the front fan exit and the spacing between the front and rear thrust vectors. These features help ease the problems of configuring the aircraft layout for stable pitch control in hover. The added attraction of the SPTF is in up and away flight, where the engine converts to serles mode operation as a mixed flow turbofan (with afterburner) with all the advantages of this engine 
type in fuel consumption and dry or augmented performance.

However, the key uncertainties of the SPTF are in its complexity to allow dual-mode operation. Separation of the fan into front and rear sections adds length and can cause problems in shaft alignment. A flow diverter scheme is needed behind the front fan. The alrcraft layout must allow for a secondary rear fan intake and a secondary nozzle system for the forward fan. These features can contribute to high weight and volume requirements in a tander fan engine Installation.

A discussion of the operation of the SPTF engine is presented, along with the influence of its cycle design parameters on engine performance, weight, and dimensions. Reduced fuel consumption by operating the engine in parallel (high bypass) mode during subsonic flight is also examined. Alternative design concepts for the front fan flow diverter are considered for possible advantages in engine performance and/or decreased engine length. Optional methods for short takeoff with vectored thrust are described. Fan stream burning, or burning in the exhaust of the front fan, is assessed as a means of increased engine thrust in the parallel mode. Examples of SPTF installations in two alrcraft planforms, a delta-canard and a forward swept wing, are given. To complete the discussion, performance requirements for the propulsion system at critical points in a STOVL mission are compared with the capabilities of typical SPTF engines.

\section{DISCUSSION}

\section{Engine Operation in the Mission}

Figure 1 illustrates the operation of the SPTF engine at various potnts in a mission for an advanced STOVL flghter. The short takeoff at step 1 is concelved to take place with the engine operating in the high bypass parallel mode. The front fan and rear fan are supplled by separate air intakes. The front fan exhaust flow is "blocked" from reaching the rear fan and is diverted out the lower vectored exhaust. The rear fan and core of the engine operate as a mixed flow turbofan with the afterburner on. The main (or core) exhaust is also shown vectored.

In steps 2, 3, and 4 of the misstion the engine has been converted to series flow. In this case the upper intake and lower exhaust in the front section of the engine have been closed and the flow blocking device is opened to allow all the front fan exhaust to continue back to the rear fan entrance. Again, the engine operates as a mixed flow turbofan, but with a higher cycle pressure than the parallel mode, since now the pressure rise of the front fan acts to "supercharge" the remainder of the engine.

In step 5 the schematic of the engine also indicates serles mode operation. Here, however. the main afterburner is assumed of $f$ for typlcal subsonic cruise operation. As discussed later in this paper, parallel mode operation in subsontc crutse may also be used, and may be preferred.
The vertical landing mission segment, step 6. shows the SPTF converted back to parallel mode. Both the front and rear nozzles are show in vertical thrust orientation and, in this case, no augmentation is assumed in elther flowstrean.

\section{Base Engine Configuration}

A more specific cross-section schematic for an SPTF engine is shown in figure 2 . The engine configuration shown is a so-called "top inlet" arrangement since the rear fan airflow, in parallel mode, enters the engine from the top at a right angle to the engine axis. The front and rear fans are separated by an inter-fan duct or "Interduct" which, in serles mode, carries the flow of the front fan back to the rear fan. In parallel flow mode, the front and rear fans are isolated by a flow blocking device. A radial vane blocker valve has been suggested as an improvement (less flow distortion, less complexity, better closure) over the "venetian blind" concept indicated by the sketch in figure 1. In this application, the radial vane valve is of ctrcular form, and is tilted about 30 degrees off-vertical. This tilt helps shorten the interduct about one-half fan dlameter by allowing the upper surface inlet and lower discharge opentings to overlap, as in the venetian blind blocker. The lower discharge passes a 11 of the exhaust flow of the front fan when in parallel mode and, as indicated, may be closed by vanes or sliding sleeves in the serles flow mode.

The schematic in figure 2 includes a crosssection of the engine core, indicating the relative size of this part of the SPTF engine. An afterburner section is followed by a two dimensional ADEN type nozzle and, as indicated, these also add to the length of the engine. The difference in engine length with a conventional turbofan lies, for the most part, in the length of the interduct between the front and rear fans. In the top inlet configuration, the length of the interduct is about twice the exit diameter of the front fan to accommodate the required areas for the front fan exhaust and rear fan intake. The welghts of the varlous necessary parts of the interduct/flow diverter section of the engine, such as the fan shaft extenston and flow blocking devices, comprise the welght difference between the SPTF and a conventional turbofan.

\section{Thrust Split Requirements}

Convertibllity from series to parallel flow mode in the SPTF engine places unique requirements on the cycle and turbomachinery. It may be necessary that the conversion from series to parallel requires no change in physical shaft speed or combustor temperature. In addition. the aircraft configuration and destred location of the engine may require a specific value of parallel mode thrust split to balance the alrcraft in hover. The thrust split used herein is defined as the ratio of front fan exhaust thrust to the total thrust of the engine in parallel mode. For example, if the engine is installed in the afrplane such that the front and rear thrust vectors are equidistant from the alrcraft center of gravity (c.g.), a thrust split of 0.5 
(front/total) would be necessary to maintain balance (zero pltching moment).

However, most SPTF engine installations result in unequal distances between the alrcraft c.g. and the locations of the front and rear thrusts. When the engine is located rearward, with the typical deflecting rear nozzle shown in figure 2, the front vector is closer to the c.g. than the rear thrust vector. In many cases, the required thrust split may be .60 or greater. Examples of this are discussed later in this paper for typlcal atrcraft layouts.

\section{Engine Cycle Characteristics}

Table I lists cycle data for two posstble SPTF engines sized for $400 \mathrm{lb} / \mathrm{sec}$ front fan alrflow at the sea level static (5.1.5.) condition. The englnes shown here were selected to have parallel mode dry thrust splits (front/ total) of about .60 . The baseline series mode turbofan design parameters are listed in the first column for each engine at an assumed 97 percent inlet total pressure recovery. The serles mode bypass ratio (BPR) is .60 for engine 1 and 1.0 for engtne 2. To meet the thrust split requirement, the design pressure ratios of the front fans (FPRI) are shown as 3.0 and 2.65 for the .60 and 1.0 bypass engines, respectively.

For each of the above front fan pressure ratios, the rear fan and compressor pressure ratios are chosen such that the nominal overall pressure ratio (OPR) of the serles mode engine 15 30. It is actually 29.1 in these cases. The rear fan pressure ratio is also selected such that the engine operate as a mixed flow turbofan, having nearly equal total pressures at the exits of the bypass duct and low pressure turbine.

Conversion from serles to parallel mode is shown in the second column for each engine. Here, the inlet recovery for the rear fan alrflow is assumed to be .95 . As mentioned earlier. the conversion is required to occur with no change in physical rotational speeds of etther spool. Also, at conversion, the front fan is operated at design corrected atrflow and pressure ratio. The rear fan and core compressor corrected shaft speeds, $(N / \sqrt{\theta})$, however, are designed to rise to 100 percent in the parallel mode. In effect, the rear fan and core compressor are at their "design points" in the parallel mode. The front fan is at its design point in etther mode.

Each engine in Table I shows the reduction in peak cycle pressure caused by the conversion to parallel mode. The supercharging effect of the front fan on the core engine is not present in parallel mode. The rear fan operating pressure ratlo increases by about 20 percent, but in engine 1 for example, the cycle peak pressure drops from 29.1 to 16.6 atmospheres. Due to the lack of supercharging, the physical atrflow of the core also drops, in this case from 243 to $138 \mathrm{lb} / \mathrm{sec}$. The comblned effect of lower atrflow and lower cycle pressure translates into thrust loss. The increased overall bypass ratio of the engine has, however, mitigated this thrust loss. Note that, in engine 1 , the gross thrust drops from 34874 ib to 28504 ib at conversion from sertes to parallel, a loss of about
18 percent. Of course, the engine thrust in parallel mode is now redistributed for purposes of vertical landing or short take of $f$.

\section{Thrust Reduction at Converston}

The drop in thrust at conversion from serles to parallel for a parametric range of SPTF engines is shown in figure 3 . The ratio of gross thrusts in parallel and serles mode depends on thrust split and the series mode design BPR. Design OPR (nominal) is held constant at 30 . The figure is a carpet plot with lines of constant dry thrust split and series mode BPR. Dashed lines are overlald on the figure to ind 1 cate the front fan pressure ratio. Note that the gross thrust ratio can drop below .80 if the destred dry thrust split is about .70. Figure 3 indicates that low values of front fan pressure ratio help to keep the parallel/serles thrust ratio high. However, fan pressure ratios below 2.7 may not result in satisfactory values of thrust sp11t.

\section{Effect of Intake Pressure Loss}

In parallel mode the frant and rear fans of the SPTF engine have their airflows supplled by different intakes. Losses in total pressure in these separate intakes can also have a strong effect on the total thrust of the engine in parallel mode. Figure 4 shows the combined effect of total pressure recovery in the intake of each fan flowstream. The sensitivity of the rear fan intake to total pressure loss can be seen to be nearly twice that of the front fan's intake. Gross thrust in the parallel mode drops by about $1 / 2$ percent for each percent drop in front fan intake total pressure, but the thrust drop due to rear fan intake pressure drop is 1 to 1. Careful design consideration must be given to the rear fan intake to minimize pressure loss and its effect on thrust.

\section{Engine Weight and Dimensions}

Table II lists weights and oimenstons for the two engines of Table $I$. The data in Table II is based on output from the NASA Lew's NNEPWATE computer code. The code performs a cycle analysis and a preliminary mechanical design of the engine to establish basic weight and dimenslons for the components. The weights are "bare" engine weights, which omit the main inlet, controls, accessorles, and all nozzles except the main nozzle. The design corrected airflow of the front fan, $400 \mathrm{lb} / \mathrm{sec}$, results in a 48 inch tip diameter in this fan for each engine. The englnes require a 7 foot long, 170 lb. Shaft extension between the front and rear fans. Extra bearing weights are included in the fan frame weights. The interduct, also 7 feet long, including blocker valve and closure mechanisms for the top intake and bottom exhaust, is esti. mated to weight $500 \mathrm{lb}$. in each engine. Note that the total engine weights are quite similar. with most of the difference in weight and length in the core. This effect applies, in general, over a wide parameter range of SPTF engines when the front fan alrflow is flxed. 


\section{Engine Thrust to Weight Ratio at Landing}

Since the STOVL airplane must land vertically, the parallel mode thrust to welght ratio is an indicator of the engine weight which must be carried by the aircraft. A preliminary weight and performance analys is of a parametric range of SPTF engines was made and the results are given in figure 5. Bare engine weights are used in the figure, as in the discusston of Table II. Thrust/weight in parallel mode is shown to depend on thrust split and serles mode bypass ratio (BPR). Again, a series mode design nominal OPR of 30 is assumed.

Note that higher thrust splits result in lower engine thrust/weight. Decreased sertes mode BPR can increase the thrust/weight, but the overlaid lines of constant front fan pressure ratio indicate that low BPR or high split calls for very high front fan pressure ratio. Front fan pressure ratlos greater than about 3.4 may not be practical in a two stage fan.

If the SPTF airplane is to be an effective competitor, the penalties in thrust loss and engine weight that have been discussed must be offset by alrcraft design and operational advantages, including short takeoff and vertical landing. These prospects are discussed in the following sections.

\section{Engine SFC in Subsonic operation}

Many missions for these aircraft, even the advanced STOVL fighter, may require large subsontc segments consisting of long crulse range or high lotter time. The dual mode (high bypass vs. low bypass) capability of the SPTF engine may provide an additional advantage for the airplane in fuel consumption if it can be designed to allow parallel operation in subsonic flight. $7-8$

Figure 6 compares series and parallel operation of a typical SPTF engine at subsontc speeds. Thrust specific fuel consumption (TSFC) is shown at different net thrust levels for a $400 \mathrm{lb} / \mathrm{sec}$ (s.1.s.) engine stze. The TSFC advantage for parallel mode operation is clearly seen at each combination of flight Mach number and altitude. The TSFC difference is largest at the lowest Mach number (0.4) and appears to decrease as the Mach number is increased to 0.85 .

The combinations of flight Mach number and altitude are selected such that the dynamic pressure, $q$, is nearly the same in a 17 cases. For a given alrcraft $11 \mathrm{ft} / \mathrm{drag}$ ratio (L/D), constant q can be interpreted as constant thrust requirement, allowing the curves of TSFC to be compared vertically in figure 6 . The $q$ used in the figure, $1971 \mathrm{~b} / \mathrm{ft}^{2}$, corresponds to nearmaximum $L / D$ operation of a typlcal fighter type alrcraft with a wing loading of about 70 $\mathrm{lb} / \mathrm{ft}^{2}$. For a 30000 lo aircraft, the thrust requitrement will probably be about 3000 to 4000
lb.

If the mission has a lotter segment, maximum lotter time (or minimum loiter fuel) depends solely on minimum TSFC at the required thrust. Here, for the given thrust, the best lotter condition in parallel mode is $M=0.6$ at an altitude of $25000 \mathrm{ft}$. The TSFC is about 10 percent less than the best loiter condition for series mode, $M=0.85$ at $40000 \mathrm{ft}$. Cruise range, however, depends on the ratto M/TSFC. Hence, in figure 6 , the best cruise condition is $M=0.85$ at an altitude of $40000 \mathrm{ft}$.. With parallel mode still showing a small advantage over series mode.

\section{Alternate Diverter valve Systems}

The top inlet configuration for the SPTF described in figure 2 may not easily lend itself to operation in flight at subsonic speeds, especlally with the lowest possible loss of total pressure in the rear fan flowstream. Provision must also be made for vectoring the front fan exhaust in the flight direction.

An alternative front fan flow diverter which does not requite the top inlet flow for the rear fan has been suggested for the SPTF. The schematic in figure 7 shows the engine equipped with an annular inverter valve (AIV). The AIV is a flow switching device which allows a peripheral intake to be distributed around the front fan case. The peripheral intake supplies alrflow to the rear fan coaxlally with the flow of the front fan when the AIV is positioned for parallel flow. In this concept, the entire assembly could be located inside the airplane, aft of the diffuser section of the main (supersontc) inlet.

In the AIV, two cylindrical halves of the valve are made to move (rotate) in clock position relative to one another. Thts movement changes the allgnment of flow passages to allow an inner to outer reversal of flow stream positions at the AIV exit. If the valve is made in the form of 12 sectors, a 30 degree movement of one valve half relative to 1 ts mate wlll produce the flow switch. Referring to the sketch of the AIV in figure 7, the incoming outer flow at $A$, exits the valve as the inner flow at A2. Similarly. the inner flow at $B$ exits the valve as the outer flow at $B 2$. When rotated back 30 degrees to the initial vaive position, the flows enter and exit the AIV without switching.

In the SPTF engine the pertpheral intake to the AIV is only used in the parallel mode. In series mode, the outer portion of the AIV and the peripheral intake are not flowing. In parallel mode, the flow of the front fan is conducted through the AIV to enter a collarshaped wrap-around plenum chamber. This plenum, in turn, feeds two vectorable exhaust nozzles simflar to the front nozzles of the current Rolls-Royce Pegasus engine in use on the Harrler AV-B. Also in parallel mode, the peripheral intake flow is conducted through the AIV to the fan interduct and then to the rear fan.

Design of the SPTF with an AIV can greatly reduce the spacing between the front and rear fans in the interduct, and may be of further advantage to the STOVL airplane by allowing an axial orientation for the rear fan flow. This concept not only seems more adaptable to parallel mode engine operation in forward flight, but also may allow more even distribution of the flow and less distortion at the rear fan face. The perlpheral intake may also be used to advantage in sertes mode operation to help reduce main inlet spillage drag if designed to provide 
a means of conducting inlet bypass flow overboard through the unused front nozzles.

The inclusion in the design of Pegasus-type vectoring nozzles may be advantageous to the alrcraft in subsonic crulse and preparation for vertical landing. The advantage of vectored thrust in short takeoff w1ll be discussed in a later figure. The drag of the fan nozzle projections must, of course, be considered in series mode operatian. Covering, falring, or retraction methods would be destrable.

The AIV may help shorten the engine length. but it requires an increase in diameter and its weight may not be less than the top inlet interduct system. Design of the flow passages for low frictional pressure loss and leakage is also critical. since they must carry the engine flow at all times, whether operating in series or parallel mode. The sensitivity of engine performance to pressure losses in the fan flow streams was discussed earlier.

Figure 8 shows an engine schematic for another possible type of perfpheral intake flow diverter system for the SPTF. The concept in figure 8 has a peripheral intake for the rear fan airflow with the same flow area requirement as the AIV system of figure 7. However, this so-called "sleeve value" system does not use a flow inverter behind the front fan. The front fan exhausts into the interduct, the forward volume of which functions as a plenum (in parallel made) for the front nozzles. The front nozzles could be the same vectorable Pegasustype nozzles mentioned for the AIV system. In parallel mode, the front and rear fans are isolated by a vaned blocker valve, simllar to the top inlet system, in this case vertically orlented.

For parallel mode flow to the rear fan, the peripheral intake alrflow is led to a circumferential arrangement of inlet ports. These ports are opened by a rotating sleeve in the interduct space between the blocker vanes and the rear fan face. In serles mode, this sleeve is rotated to close the rear fan entry ports, the front nozzle exhausts are also closed by a movable sleeve, and the radtal vane blocker is opened.

The sleeve valve flow diverter may not be lighter than the AIV system and does not have the potential of reducing the interduct length that may be found in the AIV. However, its advantage is that in serles mode operation the flow between the front and rear fans encounters only the vanes of the blocker device and may therefore expertence less frictional pressure loss. Another possible advantage is that the front fan exhaust thrust in parallel mode is moved forward to a position nearer the exit of the front fan.

As mentioned above, peripheral intake concepts increase the engine dlameter. The increase 15, however, not excessive. Figure 9 shows the total diameter requirement of pertpheral intake around the circumference of the 50 -1nch diameter fan case of a $400 \mathrm{lb} / \mathrm{sec}$ front fan. The peripheral flow area is set by the corrected flow requirement of the rear fan in parallel mode. This rear fan airflow is about half the front fan airflow, and decreases with increased front fan pressure ratio. For example, the cycle data in Table I shows the rear fan corrected airflow of 212 and $194 \mathrm{lb} / \mathrm{sec}$ at front fan pressure ratios of 2.65 and 3.0 . A rear fan corrected flow of $200 \mathrm{lb} / \mathrm{sec}$ is half the flow of the front fan. Hence, at equal flow Mach numbers, the total frontal area of the front fan case and peripheral system must increase by 50 percent. In this example, the required frontal diameter would be 61.2 inches. with an annulus helght of less than 6 inches.

In figure 9 , the total diameter varies from 60 to 64 inches over a wide range of front fan pressure ratios, corresponding to an annulus height of 5 to 7 inches. It is noted that the increased dlameters represent an increase in frontal area of the propulsion system by 40 to 60 percent. This increased frontal area may effect the airplane drag, depending on the design of the engine installation.

Each of the perlpheral intake flow diverter concepts discussed in figure 7 and 8 also lead the front fan exhaust out through ducts which could be equipped with vectorable nozzles. If so designed, the SPTF engine could use thrust vectoring of the fore and aft nozzles on the alrcraft to achieve very short takeoff runs.

\section{Vectored Thrust Short Takeoff}

Figure 10 shows a sketch of the STOVL airplane at takeoff rotation point with an angle of attack, $a$. The alrplane has front and rear thrust vectors $F_{1}$ and $F_{2}$ oriented to the vehicle axts by the angles $\delta_{1}$ and $\delta_{2}$. A value of zero for each would indicate axial thrusts. At liftoff rotation, or in flight, the vector angles $\delta_{1}$ and $\delta_{2}$ are related such that the aircraft has zero pitching moment. Hence, $\delta_{2}$ is a function of $\delta_{1}$ and the thrusts $F_{1}$ and $F_{2}$. Each of the thrusts, $F_{1}$ and $F_{2}$, can be expressed as functions of the total thrust and the thrust split (front/total). Therefore, for a given takeoff distance, the required thrust/weight of the alrcraft can be given by $\alpha, \delta_{1}$ and split.

Results are shown in figure 10 for two types of takeoff with a ground run of 400 feet. Type $I$, for less complexity, fixes the vector angles of $F_{1}$ and $F_{2}$ during the ground acceleration run of the aircraft. Hence, the Type I takeoff uses less than all of the avatlable engine thrust for acceleration down the runway. The Type II takeoff is more complex by assuming that the front and rear vector angles are changeable during the takeoff. Both the fore and aft nozzles are assumed capable of full hortzontal positioning during the acceleration ground run. Hence, the alrcraft uses the maximum avallable thrust to accelerate, minimizing the required thrust loading. At the proper rotation velocity, the vectors must be plvoted to positions $\delta_{1}$ and $\delta_{2}$, which add their vertical components to the lift generated by the wing such that the tatal equals the alrplane welght.

In the cases shown in figure 10 , the rear nozzle thrust is assumed augmented by 40 percent with an afterburner. The front nozzle thrust is 
not augmented. The thrust split (front/total), dry, is .60 in each takeoff figure. Although the rear nozzle is augmented, the requitred alrplane thrust/weight values given are for dry operation in the parallel mode for easler comparison of the options. Hence, the actual thrust/weight employed on the alrcraft is greater than that shown. The very small effect of thrust split is indicated by the dotted lines in the Type I takeoff results. Both figures show the effect of $\alpha$ and $\delta 7$ on the required thrust/ weight. The angle of attack at rotation should correspond to the maximum lift coefficient for the aircraft. To avoid a reverse component of the front thrust vector at the rotation point, the vector angle $\delta_{1}$ must be limited such that the sum of $\alpha$ and $\delta_{1}$ is less than 90 degrees. A value of $\delta_{1}$ of about 50 degrees appears to be sufficient in either type of takeoff.

Figure 10 shows a 15 to 20 percent reduction in required thrust for the Type II takeoff. However, the less-complex Type I takeoff is still possible with thrust loadings less than 1.0 and may be desirable if other mission requirements have already sized the engine to the thrust/weight levels required for this takeoff option.

\section{Augmentation by Fan Stream Burning}

In the takeoff of figure 10, only the core engine exhaust (rear) is augmented, using the engine afterburner. The engine afterburner can be used for thrust augmentation in both series and parallel mode operation in most segments of the STOVL mission, with the exception of vertical landing. As mentioned in figure 1 , the vertical landing segment of the misston normally assumes dry (non-afterburning) thrust in both the front and rear nozzles.

It has been suggested that, if the appropriate technologies are avaliable, the SPTF engine performance could be markedly improved by afterburning the front fan exhaust in parallel mode. Thls concept has been called Fan Stream Burning (FSB). The thrust augmentation of an afterburner is proportional to the square root of the stream temperature ratlo across the burner. In the FSB concept, the burner entry temperature is that of a typical fan exhaust (700-800 OR). Hence, the total temperature of the FSB exit need not be extremely high to produce significant thrust increases.

Figure 11 shows the effect of FSB in the SPTF engine on thrust split and overall thrust in the parallel mode. Three values of FSB exit temperature are shown, 1200, 1800, and 2400 $O_{R}$. Note that for an FSB temperature of 1800 $o_{R}$, an engthe with a dry paralle? mode thrust split of .5 can have a thrust split of about .6 with FSB. The other part of $f$ igure 11 shows that this SPTF engine (.6 spitt, $1800^{\circ} \mathrm{R}$ FSB) also benefits from a 30 percent increase in total thrust in the parallel mode. Figures 3 and 5 , earlier, indicated that the lower values of thrust split (dry) resulted in higher ratios of parallel/series gross thrust and higher ratlos of parallel thrust/engine weight. The SPTF engine then doubly benefits from FSB by allowing high values of parallel mode thrust split along with increased thrust/weight.
The effect of FSB on the SPTF engine thrust/ weight is shown in figure 12 for the parametric range of engtines covered in figure 5. The results in figure 12 are based on an FSB temperature of $1800^{\circ} \mathrm{R}$. The data in the figure includes a 6 percent increase in engine weight to allow for the weight of the FSB burners. The lines of constant serles mode $B P R$ now exhibit maximum thrust/weight at thrust splits between .6 and .7 instead of the steady fall-off that was shown in figure 5 . This is caused by the reduced effect of FSB at lower values of split shown in figure 11, coupled with the strong decrease in thrust/weight shown in figure 5 for dry, parallel mode thrust splits above .6.

\section{Fan Stream Burning at Takeoff}

When FSB is used in vectored thrust takeoff, required thrust loading on the alrcraft can drop significantly below the values shown earlier in figure 10 . In figure 13 , the required (dry) thrust/weight of the aircraft in parallel mode is shown for a Type II takeoff. In this case the dry split of the SPTF engine is .5 and the FSB temperature is $1800^{\circ} \mathrm{R}$, resulting in an FSB split of about .6. As in figure 10, the afterburner of the engine is assumed on, augmenting the rear thrust of the engine by about 40 percent. The augmentation of the front thrust vector, with the FSB at $1800^{\circ} R$, is almost 60 percent. The rotation angle of attack, $\alpha$, is set at 15 and 20 degrees. Curves from figure 10 are repeated here to compare the FSB results with those without FSB.

As stated earlier, the potential performance gains with FSB depend on the readiness of the required technologies. However, the operational demands on the FSB are not severe, since it is intended only for use at low flight speeds and zero altitude. This is less demanding than the needs of the proposed plenum chamber burner (PCB) on Pegasus type vectored thrust separate flow turbofans. The PCB systems are intended ta provide fan stream thrust augmentation over a broad operational envelope (altitude and Mach) of the vectored thrust fighter-type aircraft.

\section{Fan Stream Burning at Landing}

One serfous consideration for all applications of fan-stream thrust augmentation by burning is re-ingestion of warmer amblent air. The nearness of the front fan exhaust and the engine inlet, along with the mixing of the hot fan stream exhaust with the atmosphere around the atrcraft, can radically decrease the engine thrust. In short takeoff operations, the probabillty of such ambtent temperature rise is quite low, since the alrcraft is in motion. However, in vertical landing of the STOVL airplane, this type of thrust loss could be devastating. The patterns of hot jet mixing and re-ingestion in the environment of the airplane at static conditions must be better understood and predictable.

Figure 14 shows the decrease in gross thrust (in parallel mode) of a typlcal engine with and without FSB. The FSB temperature used here is $1800^{\circ} \mathrm{R}$. Note that at zero degrees ambient temperature rise, the SPTF engine with FSB has a relative thrust of 1.3 , in agreement with figure 
11. The figure shows that if the amblent temperature rise at the SPTF inlet is only $67^{\circ} \mathrm{R}$, all the thrust increase due to FSB can be cancelled. An interesting side effect, noted in the figure, is that the thrust splits, with or without FSB, remain nearly constant as the amblent temperature rises.

\section{Engine Installations in Aircraft}

Two aircraft are sketched in figure 15 , Hllustrating installations of the SPTF engine. The engine canfiguration chosen for this figure is the AIV diverter valve design with vectorable front fan nozzles. Each engine also includes a two-dimenstonal vectorable rear nozzle. The front fan and peripheral intake is fully enclosed in the fuselage, aft of the diffuser section of the main inlets. Positioning of the engines in the fuselage is nearly conventional, except for the more-forward location of the front fan.

The locations of the SPTF engines result in minimum compromise of the airframe for high performance flight capability. The forward nozzles projections may, however, contribute to drag. Location of the airframe c.g. in etther airplane appears to result in a longer moment arm for the rear nozzle. The rat to of the moment arms of the front and rear nozzles is about $1.5: 1$, hence, the hover thrust split must be about .60 .

The two alrcraft are a forward swept thin supercritical wing (FSW) with relaxed static stabllity and a blended delta wing/body with a large canard (Delta Canard). The FSW sketch is based on the Grumman $X-29$ CTOL demonstrator atrplane, a joint DARPA/USAF/NASA program. The Deita Canard concept is based on the vought TF120, a V/STOL design study done for a Navy/NASA wind tunnel program.

The FSW planform has shown, in wind tunnel tests, a lower wave drag than conventional aft swept wings. The alrcraft should also have improved low speed aerodynamic control due to the location of the allerons near the atrcraft center of gravity and in a thinner boundary layer, since the layer is less apt to thicken from cross-flow alang the wing. As a STOVL atrplane, the nigher aspect ratio (compared to a delta wing) and the location of the wing tips near the c.g. could reduce reaction control power requirements. The FSW geometry also appears to allow a favorable separation of the wing carry-through structure and the larger components of the installed engine. In many $V / S T O L$ designs, the closeness of the engine and wing carry-through can compromise fineness ratio and area ruling. It is belleved, but not yet demonstrated, that the FSW alrcraft can be more compact than conventionally designed atrcraft. A compact configuration with good STO performance could be attractive for shipboard operations. Low wave drag and exceptional attitude controi aspects favor the atrplane as a transonic fighter.

The Delta Canard configuration has a blended wing/body similar to the SR-7l (high altitude supersonic crulse), except for being a single engine alrplane with a large canard. The benefits of a blended delta are low supersonic drag and possible survivability advantages. The delta wing has a lower span for the same area and often does not need wing fold for ship storage. It also provides about 10 percent more internal fue 1 volume and 20 percent less wetted area than a higher aspect ratlo wing of the same size. The long wing root and carry-through structure could present an integration problem with the SPTF engine. The fuselage may require more volume and length for fineness ratio and area rule considerations. Directlonal stabllity is an important factor in any long nose alrplane. but the Delta Canard may need more tall area (usually twin talis) which further increase wetted area. It is noted that the above comments about configurational differences are generaltties, the detalls of which are beyond the scope of this paper and need documentation by wind tunnel testing and systems integration studies.

\section{Performance at Key Misston Points}

Application of the SPTF engine on a typical mission is represented by Table III. The table lists key thrust points in the mission profile of an advanced STOVL fighter atrcraft. The thrust values in the table can be taken as consistent with elther of the aircraft configurations sketched in figure 15 . More detalled analysis, of course, would result in unlque thrust requirements for each aircraft. Engine requirements are given etther in the form of a thrust goal (such as for STO, VL, or dash) or a desired cruise (or laiter) segment for which the fuel consumption must be the least possible. At the STO condition, the aircraft takeoff gross weight of $350001 \mathrm{~b}$. requires a tatal thrust of about $27000 \mathrm{lb}$. for a vectored thrust takeoff with a 400 foot ground run. At the vertical landing (VL), expended fuel and payload are assumed to reduce the aircraft welght to under 25000 1b., resulting in a vertical thrust requirement of $28000 \mathrm{ib}$. The other mission points assume an aircraft weight condition of $30000 \mathrm{1b}$. to represent reduced on-baard fuel or payload.

The two engthes used in Tables I and II are again used in Table III. The performance of each SPTF engine is shown at the baseline front fan size of $400 \mathrm{lb} / \mathrm{sec}$. It can be seen in Table III that engine 1 (serles mode $B P R=.6$ ) is "over goal" at many of the key mission points. except the vertical landing. Hence, if the landing performance of the engtine could be enhanced (perhaps with FSB), the engine may be down-sized. Short takeoff (with rear afterburner) is apparently not a critical engine sizing point, therefore, FSB would not be a great advantage at takeoff except as a means of keeping very short ground run for intentional overload misstons with higher fuel or payload. The data given in the table for engine 2 (series mode $B P R=1$ ) shows that this englne also meets many of the thrust goals. It is, however, short of thrust requirements in VL and STO and would require up-sizing unless performance at these critical points is augmented.

Serles and parallel mode optlons are listed for most of the subsonic crutse (or lotter) points in Table III to again underscore the fuel advantages of operation in the high-bypass parallel mode. Note again that crutse for range 
and cruise for loiter time requires the selection of different altitudes and flight Mach number.

Data such as in Table III are not, of course, a substitute for parametric mission analysis, systems integration, and alrcraft configuration studies. An aggressive examination of the SPTF engine in realistic alrcraft layouts in which the best features of the engine are comblned with the airplane configuration is needed, as it is for all STOVL propulsion concepts.

\section{CONCLUDING REMARKS}

The preferred future STOVL fighter will, of necessity, be a multi-mission alrcraft. Military strategy, logistics, and economics issues will emphasize high levels of effectiveness for the atrcraft in flghter/intercept, attack/bomber. and long loiter air patrol roles. Fixed cycle propulsion concepts may not successfully perform all these functions. This is the area of opportunity for the dual-mode SPTF engine.

Dual mode capability in the tandem fan was originally intended for vertical operations, but it has been shown that the high bypass parallel mode in subsontc cruise can reduce fuel usage. Parallel mode cruise may require new features such as special configuration for the rear fan intake and Harrier-type front nozzles for the fan exhaust. But with such nozzles on the aircraft and afterburning at the rear nozzle, high performance fully-vectorable short takeoff is possible in the parallel mode. The rear fan intake may in fact be incorporated in the supersonic (main) inlet and the diverter valve could be used to reduce splllage drag in serles mode operation by conducting inlet bypass air to the (non-flowing) front nozzles.

The full effect of the unique features and operational advantages of the SPTF engine depends on careful selection of the alrcraft configuration. Alrframe/engine integration requirements, such as hover thrust split, can strongly influence engtne performance and weight and may compromise flight performance of the alrcraft. Lower thrust split in ory parallel mode (hover) is better for the SPTF engine in terms of lower required pressure ratio in the front fan, higher ratios of parallel to serles mode thrust, and lower engine weight per unit of hover thrust. Configuration of the alrcraft to reduce the required hover thrust split is a prime consideration. But the engine itself may be modified to decrease the required split by incorporating a ventral nozzle (not covered in this study). located closer to the core, for use in dry hover. The rear afterburner would st 111 be present for other sertes and parallel mode operations.

The only unique component in the SPIF system appears to be the diverter valve and interduct. The design issues here are minimum size, weight. and pressure loss. The front fan bearing structure and shaft extension may also challenge the designer with problems in minimum weight and dynamic effects.

From the viewpoint of propulsion technology in general, the SPTF engine presents the same challenges, and shares in the same potential benefits, found in all advanced propulsion systems. Technology advancement programs in inlets. nozzles, turbomachinery, combustors, and materials continue to be a critical aspect of propulsion for advanced alrcraft.

\section{REFERENCES}

1. Byrnes, J. M., Richley, G. K. and Lowry, R. B., "Views on V/STOL Tactical Fighter Alrcraft: Technology Needs and Relationships to the Runway Denial Problem," The Impact of Military Applications on Rotorcraft and V/STOL Alrcraft Destgn, AGARD CP-313, June 1981

2. Kalemaris, S. G. and Cea, R. A., "Effects of Technology Level on V/STOL Alrcraft," AIAA Paper 77-1238, Aug. 1977

3. Lewts, G. M. and Lewts, W. J., "V/STOL Status From the Engine Technology Viewpoint," AIAA Paper 81-2648, Dec. 1981

4. Boruff, W. R. and Roch, A. J., Jr. "Impact of Mission Requirements on V/STOL Propulsion Concept Selection," AIAA Paper 79-1283, June 1979

5. Kidwell, G. H., Jr. and Lampkin, B. A.. "An Evaluation of Supersonic STOVL Technology," AIAA Paper 83-2493, Oct. 1983

6. Griffin, D. E.. "Supersonic V/STOL - Tandem Fan Concepts," AIAA Paper 83-2567, Oct. 1983

7. Lutdens, R. W., Turney, G. E., and Allen, J.. "Comparison of Two Parallel/Series Flow Turbofan Propulsion Concepts for Supersonic V/STOL," AIAA Paper 81-2637, Dec. 1981

8. Wilson, S. B., III, Kidwell, G. H., Jr., Turney, G. E., and Rogers, A. "Supersonic STOVL Research Atrcraft," SAE Paper 82-1375. Oct. 1982 
TABLE I. - SPTF ENGIME CYCLE DATA

\begin{tabular}{|c|c|c|c|c|}
\hline & $\begin{array}{r}\text { Eng } \\
\text { Series }\end{array}$ & $\begin{array}{l}\text { ne } 1 \\
\text { Parallel }\end{array}$ & $\begin{array}{r}\text { Engl } \\
\text { Serles }\end{array}$ & $\begin{array}{l}\text { ine } 2 \\
\text { Parallel }\end{array}$ \\
\hline $\begin{array}{l}\text { Forward Fan } \\
\text { Ram Recovery } \\
\text { Corrected Flow, lb/sec } \\
\text { Physlcal RPM, Rel. } \\
\text { Corrected RPH. Rel. } \\
\text { Pressure Ratio (FPRI) }\end{array}$ & $\begin{array}{l}.97 \\
400 \\
1.0 \\
1.0 \\
3.0\end{array}$ & $\begin{array}{l}.97 \\
400 \\
1.0 \\
1.0 \\
3.0\end{array}$ & $\begin{array}{r}.97 \\
400 \\
1.0 \\
1.0 \\
2.65\end{array}$ & $\begin{array}{r}.97 \\
400 \\
1.0 \\
1.0 \\
2.65\end{array}$ \\
\hline $\begin{array}{l}\text { Rear Fan } \\
\text { Ram Recovery } \\
\text { Corrected Flow, Ib/sec } \\
\text { Corrected RPM, Rel. } \\
\text { Pressure Ratio (FPR2) }\end{array}$ & $\begin{array}{r}162 \\
.85 \\
1.84\end{array}$ & $\begin{array}{r}.95 \\
194 \\
1.0 \\
2.28\end{array}$ & $\begin{array}{r}180 \\
.85 \\
1.75\end{array}$ & $\begin{array}{r}.95 \\
212 \\
1.0 \\
2.13\end{array}$ \\
\hline $\begin{array}{l}\text { Core } \\
\text { Bypass Ratlo, Core (BPR) } \\
\text { Phystcal Flow, lb/sec } \\
\text { Corected Flow, lb/sec } \\
\text { Physical RPM, Rel. } \\
\text { Corrected RPM, Rel. } \\
\text { Compressor PR } \\
\text { OPR, Cycle Peak Press., atm } \\
\text { Burner, Max. Temp. OR } \\
\text { Ht Press. Turb., Rit, OR }\end{array}$ & $\begin{array}{r}.60 \\
243.3 \\
61.5 \\
1.0 \\
.88 \\
5.62 \\
29.1 \\
3660 \\
3473\end{array}$ & $\begin{array}{r}.31 \\
138.2 \\
75.5 \\
1.0 \\
1.0 \\
7.92 \\
16.6 \\
3660 \\
3458\end{array}$ & $\begin{array}{r}1.0 \\
194.5 \\
57.0 \\
1.0 \\
.88 \\
6.68 \\
29.1 \\
3660 \\
3473\end{array}$ & $\begin{array}{r}.64 \\
120.3 \\
69.5 \\
1.0 \\
1.0 \\
9.22 \\
18.0 \\
3660 \\
3461\end{array}$ \\
\hline $\begin{array}{l}\text { Rear Exhaust (Main) } \\
\text { Thrust Ib } \\
\text { Total Temp. }{ }^{O_{R}} \\
\text { Nozzle PR } \\
\text { Nozzle Throat, sq. in. }\end{array}$ & $\begin{array}{r}34814 \\
1864 \\
4.83 \\
461\end{array}$ & $\begin{array}{r}11214 \\
1874 \\
1.94 \\
542\end{array}$ & $\begin{array}{r}30753 \\
1621 \\
4.06 \\
507\end{array}$ & $\begin{array}{r}10782 \\
1614 \\
1.83 \\
576\end{array}$ \\
\hline $\begin{array}{l}\text { Forward Exhaust (Fwd Fan) } \\
\text { Thrust lo } \\
\text { Total Temp., or } \\
\text { Nozzle PR } \\
\text { Nozzle Throat, sq. in. }\end{array}$ & (n) & $\begin{array}{r}17290 \\
735 \\
2.76 \\
477\end{array}$ & 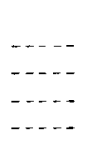 & $\begin{array}{r}16067 \\
708 \\
2.46 \\
526\end{array}$ \\
\hline $\begin{array}{l}\text { Total Thrust lb. } \\
\text { Tatal Phystcal Airflow lb/sec } \\
\text { Thrust Split, Forward/Total }\end{array}$ & $\begin{array}{r}34874 \\
388 \\
---\end{array}$ & $\begin{array}{r}28504 \\
561 \\
.605\end{array}$ & $\begin{array}{r}30753 \\
388 \\
\ldots\end{array}$ & $\begin{array}{r}26849 \\
577 \\
.598\end{array}$ \\
\hline
\end{tabular}

TABLE 1I. - SPTF ENGINE WELGHT AND DIMENSIONS

\begin{tabular}{|c|c|c|}
\hline \multirow[t]{2}{*}{ With lop Inlet Type Front Fan } & \multicolumn{2}{|c|}{ Flow Dlverter } \\
\hline & Englne & $\underset{2}{\text { Eng ine }}$ \\
\hline $\begin{array}{l}\text { Forward Fan Airflow, lb/sec } \\
\text { Forward Fan Tip Diameter, in. } \\
\text { Forward Fan PR } \\
\text { Rear Fan PR (Design) } \\
\text { Sertes Mode BPR }\end{array}$ & $\begin{array}{r}400 \\
48 \\
3.0 \\
2.28 \\
.60\end{array}$ & $\begin{array}{r}400 \\
48 \\
2.65 \\
2.13 \\
1.00\end{array}$ \\
\hline $\begin{array}{l}\text { Weight } \quad \text { lb. } \\
\text { Forward Fan } \\
\text { Shaft Extension } \\
\text { Interduct, Flow Diverter } \\
\text { Rear Fan } \\
\text { Core Engine } \\
\text { Afterburner/Nozzle }\end{array}$ & $\begin{array}{r}840 \\
170 \\
500 \\
320 \\
2190 \\
910\end{array}$ & $\begin{array}{r}830 \\
170 \\
500 \\
320 \\
2030 \\
930\end{array}$ \\
\hline Total & 4930 & 4780 \\
\hline $\begin{array}{l}\text { Length ft. } \\
\text { Forward Fan } \\
\text { Interduct/Diverter } \\
\text { Rear Fan } \\
\text { Core Engine } \\
\text { Afterburner/Nozzle }\end{array}$ & $\begin{array}{l}2.2 \\
7.0 \\
1.5 \\
7.2 \\
9.7\end{array}$ & $\begin{array}{l}2.2 \\
7.0 \\
1.5 \\
6.9 \\
9.7\end{array}$ \\
\hline lotal & 27.6 & 27.3 \\
\hline
\end{tabular}


TABLE III. - KEY POINTS IN A TYPICAL MISSION

\begin{tabular}{|c|c|c|c|c|c|c|c|c|}
\hline \multicolumn{9}{|c|}{$\begin{array}{l}\text { Supersonic STOVL Alrcraft }- \text { Takeoff Gross Welght }=35000 \mathrm{lb} \\
\text { SPTF Engines - Alrflow }=400 \mathrm{lb} / \mathrm{sec}(\mathrm{s} .1 . \mathrm{s} .) \text {. Parallel Mode Thrust Split }=0.60\end{array}$} \\
\hline $\begin{array}{l}\text { Altitude } \\
\mathrm{ft} \text {. }\end{array}$ & Mach & Flow Mode & Power & $\begin{array}{c}\text { Required } \\
\text { Thrust } \\
\text { Ib. }\end{array}$ & 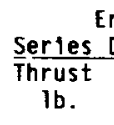 & $\begin{array}{l}\text { Ine } 1 \\
\text { 5. BPR=.60 } \\
\text { Fuel Flow } \\
\text { lb./hr. }\end{array}$ & $\begin{array}{l}\text { Eng } \\
\text { Sertes D } \\
\text { Thrust } \\
\text { lb. }\end{array}$ & $\begin{array}{l}\text { ne } 2 \\
\text { s. BPR }=1.0 \\
\text { Fuel Flow } \\
\text { lb. } / \mathrm{hr} .\end{array}$ \\
\hline $\begin{array}{r}0 \\
0 \\
10000 \\
\\
25000 \\
36000 \\
\\
\\
47000 \\
\\
10000 \\
36000 \\
50000 \\
55000\end{array}$ & $\begin{array}{r}0 \\
0 \\
.6 \\
.6 \\
.85 \\
\\
.85 \\
.6 \\
2.2 \\
1.6 \\
2.0\end{array}$ & $\begin{array}{l}\text { Parallel } \\
\text { Parallel } \\
\text { Parallel } \\
\text { Sertes } \\
\text { Parallel } \\
\text { Serles } \\
\text { Parallel } \\
\text { Sertes } \\
\text { Parallel } \\
\text { Sertes } \\
\text { Sertes } \\
\text { Sertes } \\
\text { Serles } \\
\text { Sertes }\end{array}$ & $\begin{array}{l}\text { Sto (A/B) } \\
\text { VL (Dry) } \\
\text { Crutse } \\
\text { Crutse } \\
\text { Cruise } \\
\text { Cruise } \\
\text { Cruise } \\
\text { Cruise } \\
\text { Cruise } \\
\text { Crutse } \\
\text { Max A/B } \\
\text { Max A/B } \\
\text { A/B Cruise } \\
\text { A/B Crutse }\end{array}$ & $\begin{array}{r}27000 \\
28000 \\
4200 \\
4200 \\
3200 \\
3200 \\
4000 \\
4000 \\
4000 \\
4000 \\
40000 \\
30000 \\
10000 \\
12500\end{array}$ & 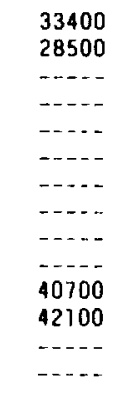 & $\begin{array}{r}39400 \\
17390 \\
3860 \\
4070 \\
2560 \\
2880 \\
3320 \\
3440 \\
3320 \\
3480 \\
66300 \\
77900 \\
12500 \\
20150\end{array}$ & 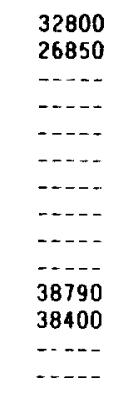 & $\begin{array}{r}41900 \\
14770 \\
3570 \\
3950 \\
2400 \\
2620 \\
3200 \\
3280 \\
3200 \\
3320 \\
66700 \\
72000 \\
13300 \\
20700\end{array}$ \\
\hline
\end{tabular}




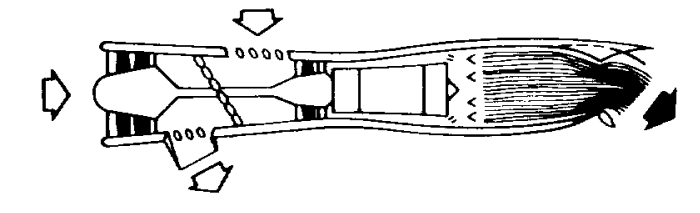

1. SHORT TAKEOFF

PARALLEL - WITH A/B

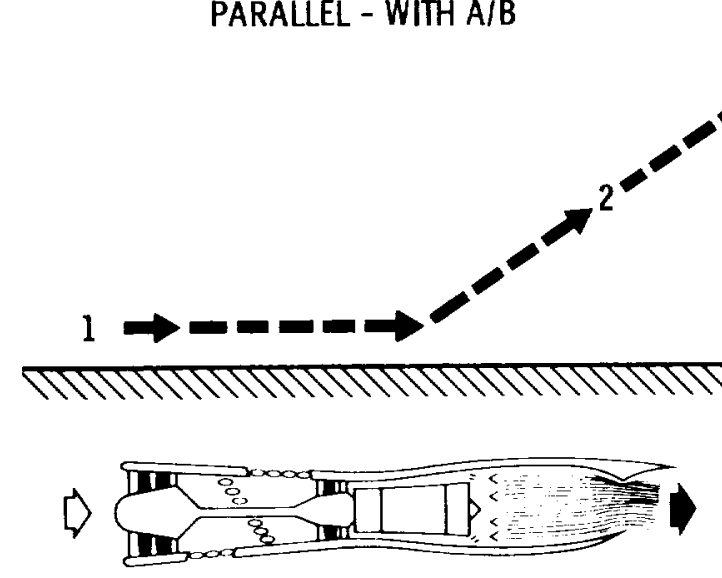

2. 3. 4. ACCELERATION, SUPER SONIC CRUISE, COMBAT

SERIES - WITH A/B

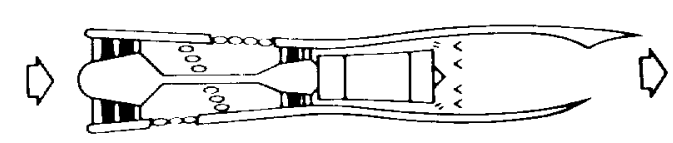

5. SUBSONIC CRUISE SERIES - DRY

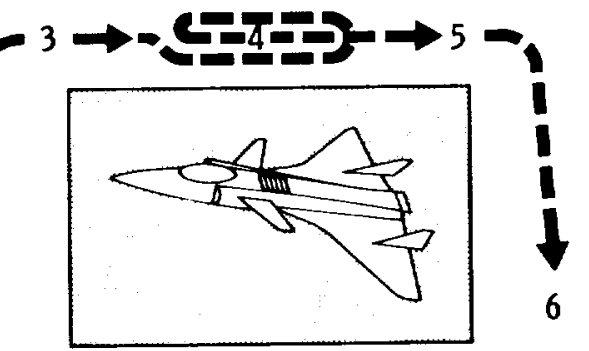

Figure 1. - Series/Parallel Tandem Fan (SPTF) propulsion for supersonic STOVL.

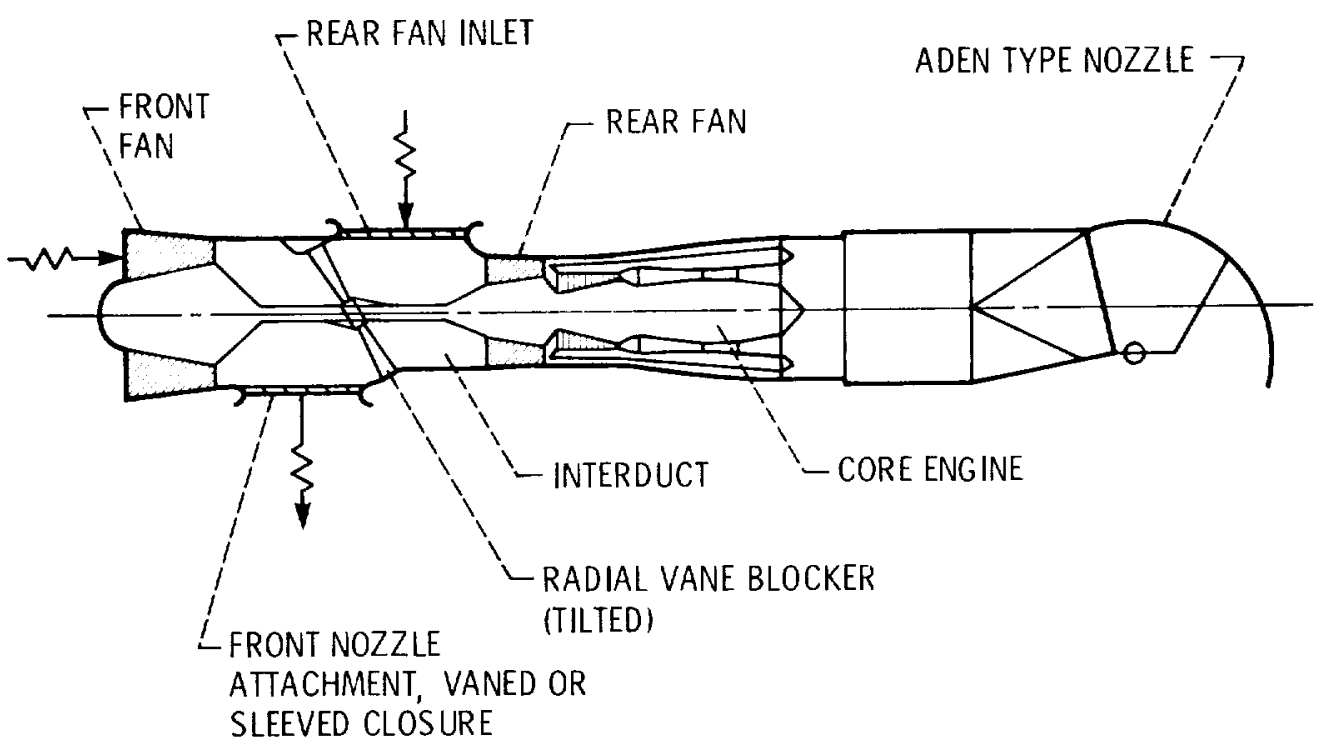

Figure 2. - Series/Parallel Tandem Fan (SPTF) in top inlet configuration. 


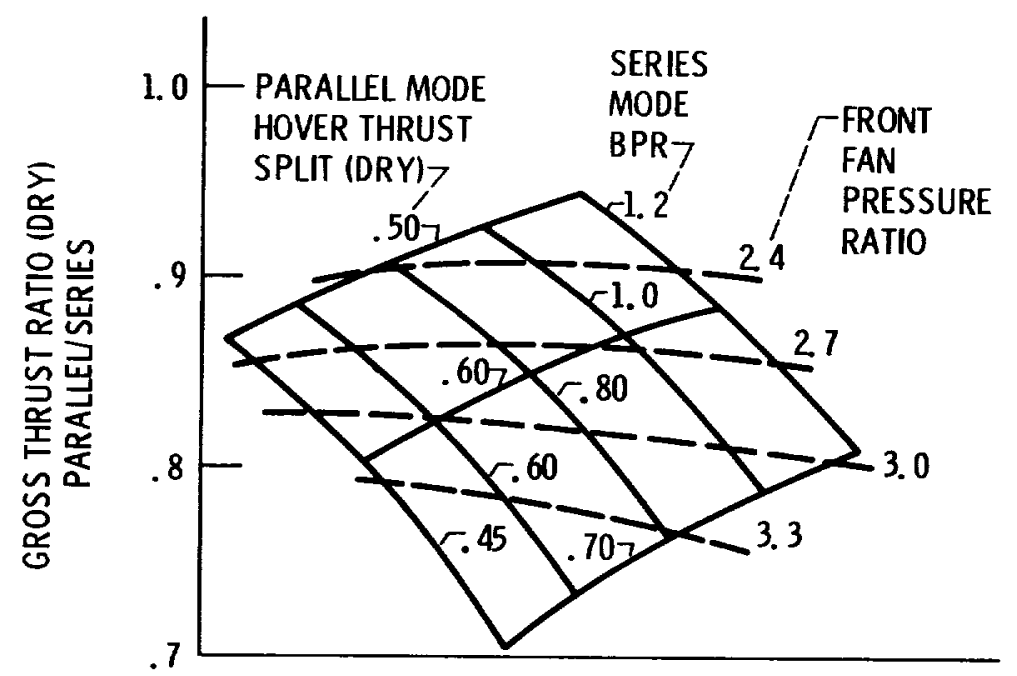

Figure 3. - Thrust reduction at conversion from series to parallel flow modes in the SPTF engine, sea level static.

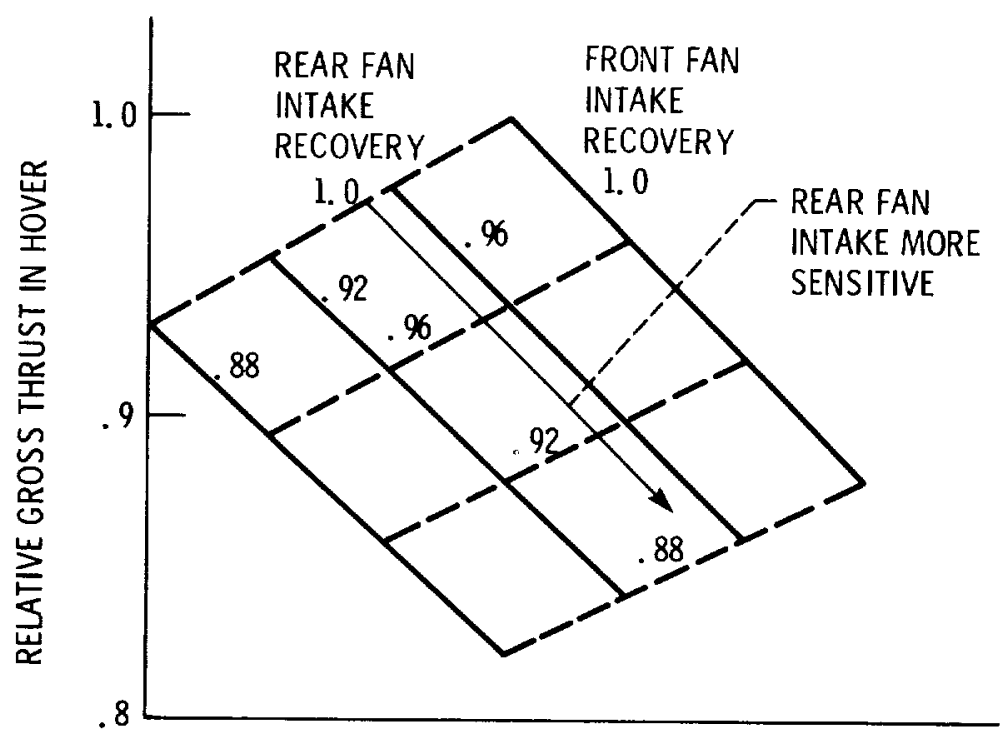

Figure 4. - Effect of intake total pressure recovery on SPTF engine total thrust in parallel flow mode, sea level static. 


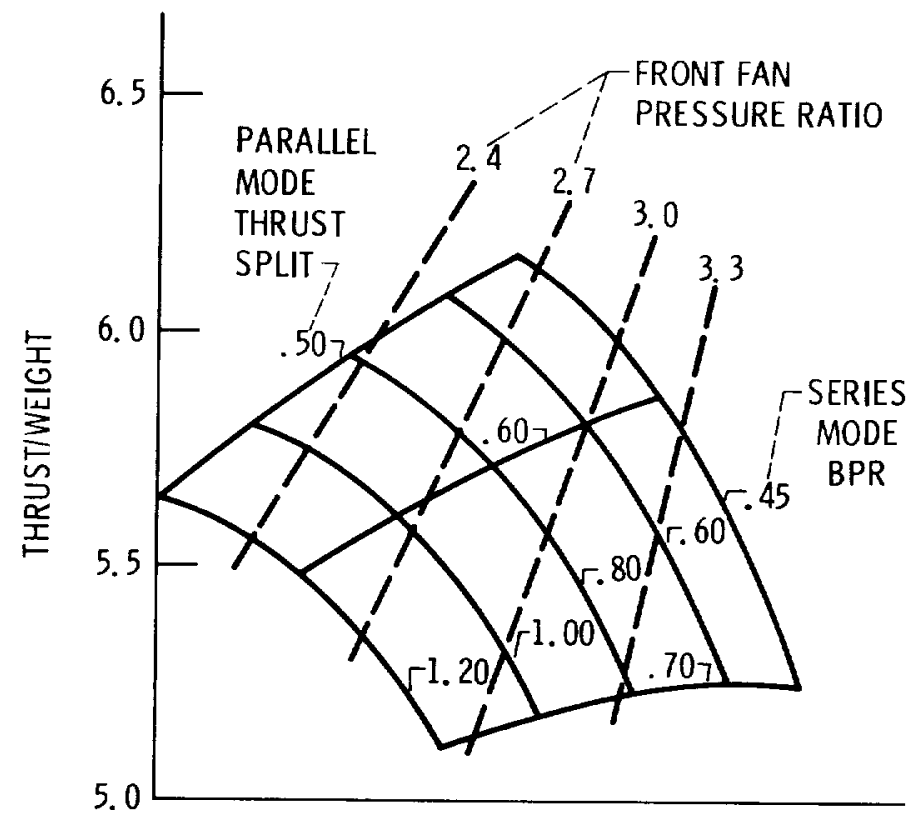

Figure 5. - Bare engine thrust/weight of SPTF engines in parallel flow mode, sea level static operation at $400 \mathrm{lbm} / \mathrm{sec}$ front fan airflow size.

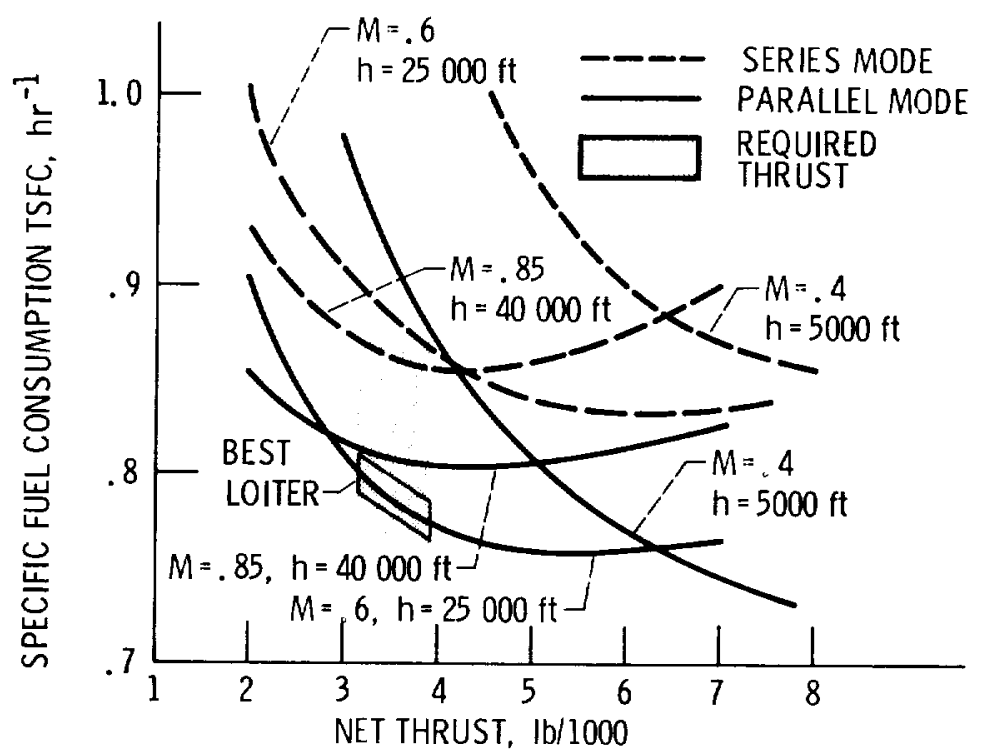

Figure 6. - SPTF Engine. Comparison of specific fuel consumption (TSFC) for series and parallel flow modes in subsonic cruise and constant dynamic pressure, $q$, of $197 \mathrm{lb} / \mathrm{ft}^{2}$; front fan sea level static airflow size, $400 \mathrm{lbm} / \mathrm{sec}$. 


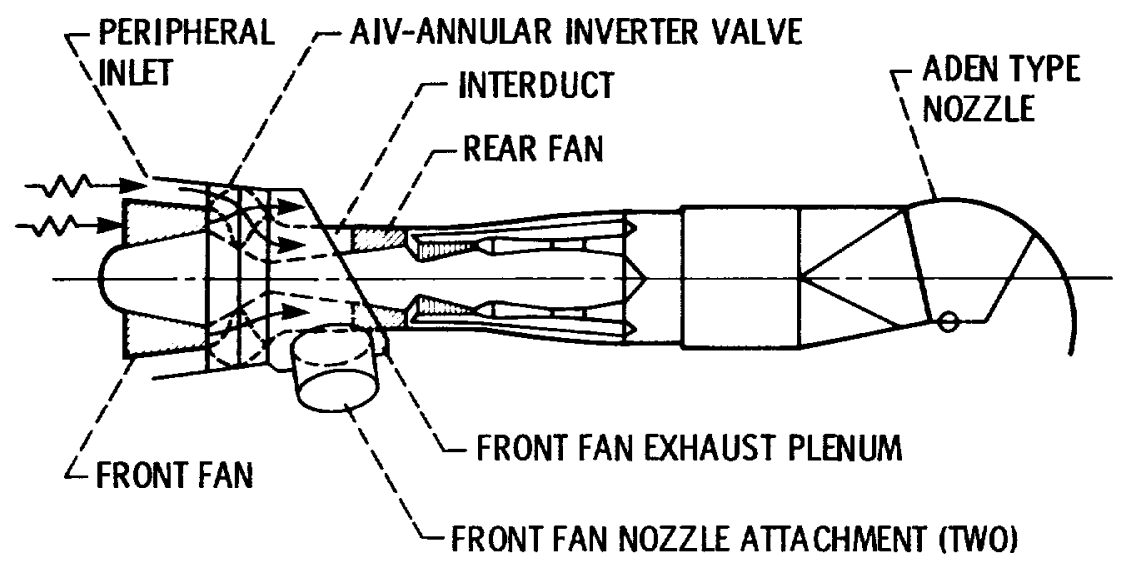

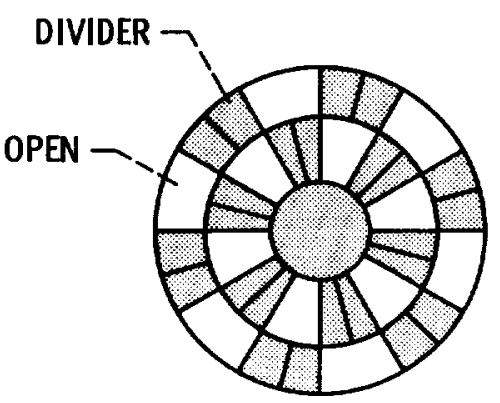

AIV - FRONT

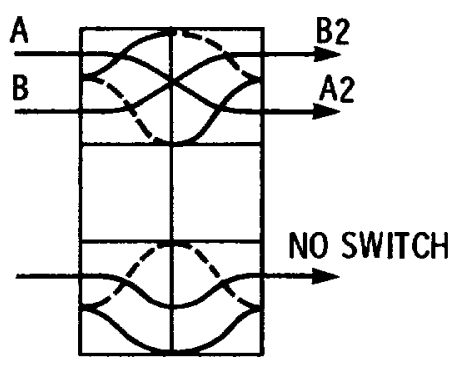

AIV

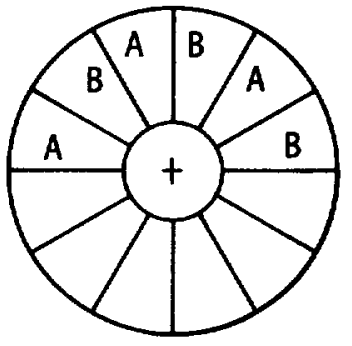

AIV - MID-PLANE

Figure 7. - SPTF engine schematic with peripheral inlet and annular inverter valve.
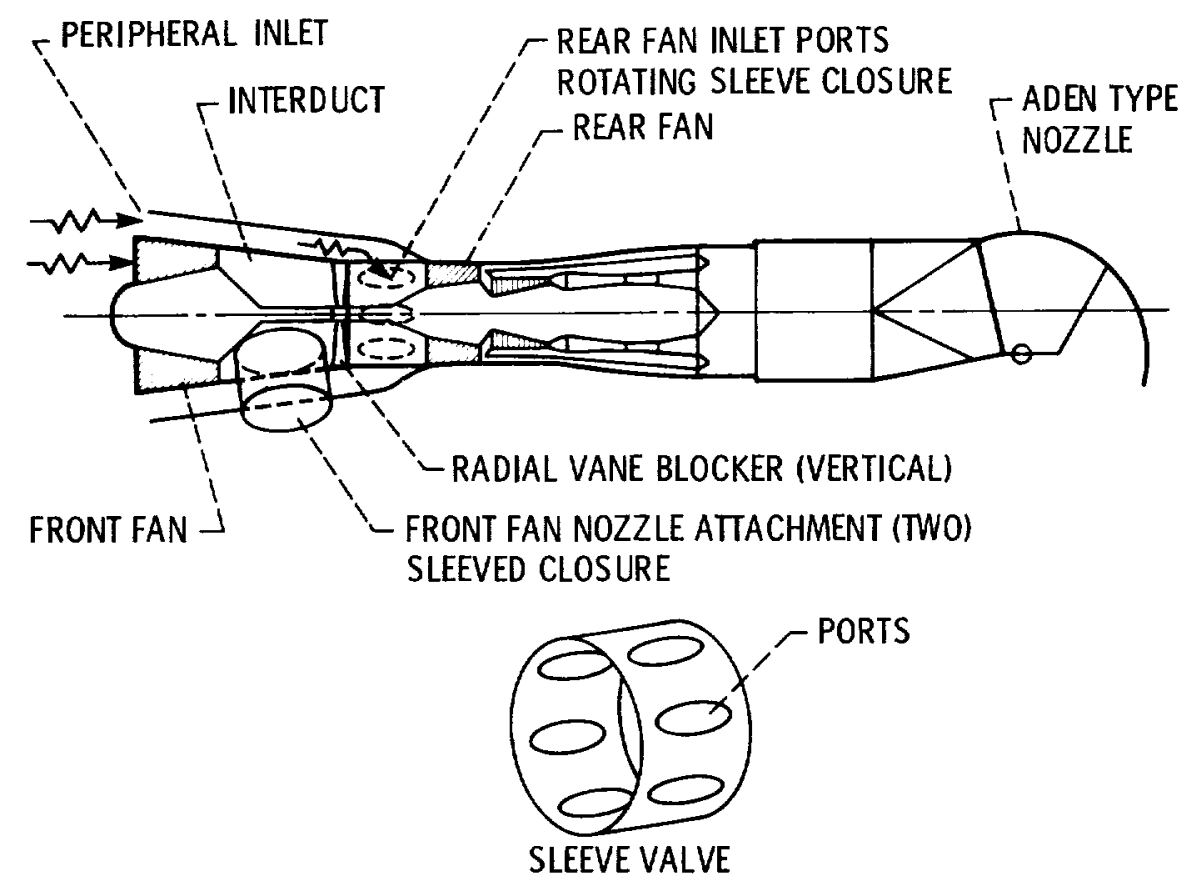

Figure 8. - SPTF engine schematic with peripheral inlet and sleeve valve for rear fan. 


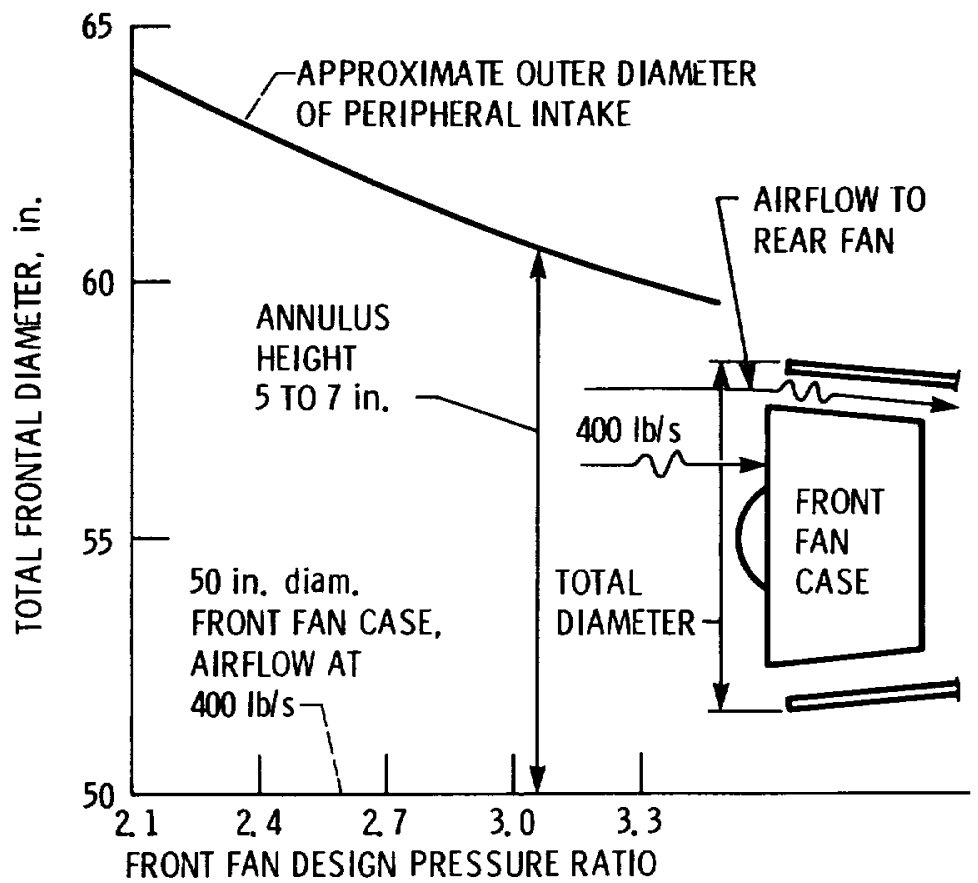

Figure 9. - Frontal diameter requirement for SPIF engines with peripheral inlets; front fan airflow size, $400 \mathrm{lbm} / \mathrm{sec}$.

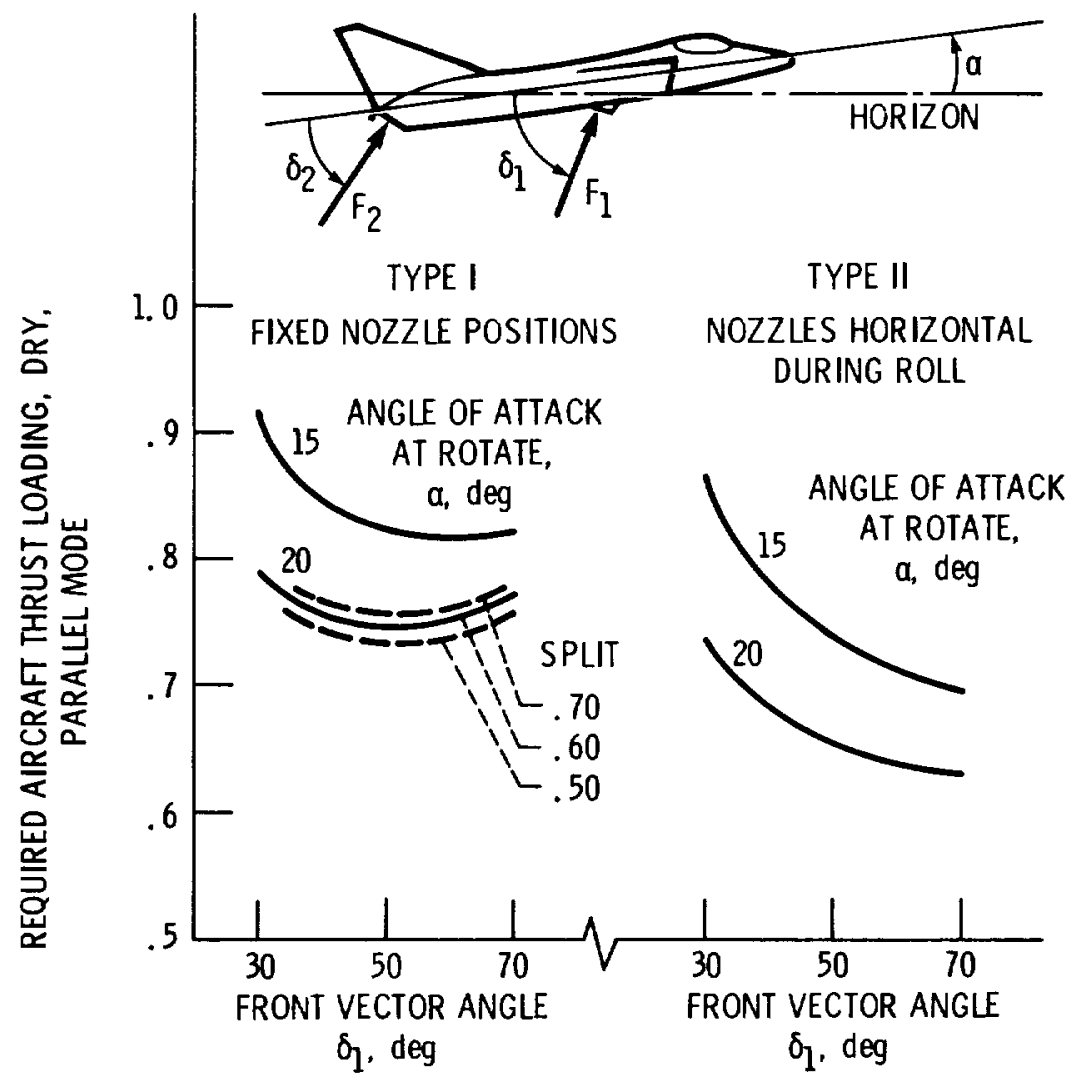

Figure 10. - Vectored thrust short takeoff for typical fightertype aircraft with SPTF engine; thrust split of 0.6 (dry); ground run of $400 \mathrm{ft}$; rear nozzle afterburner on. 


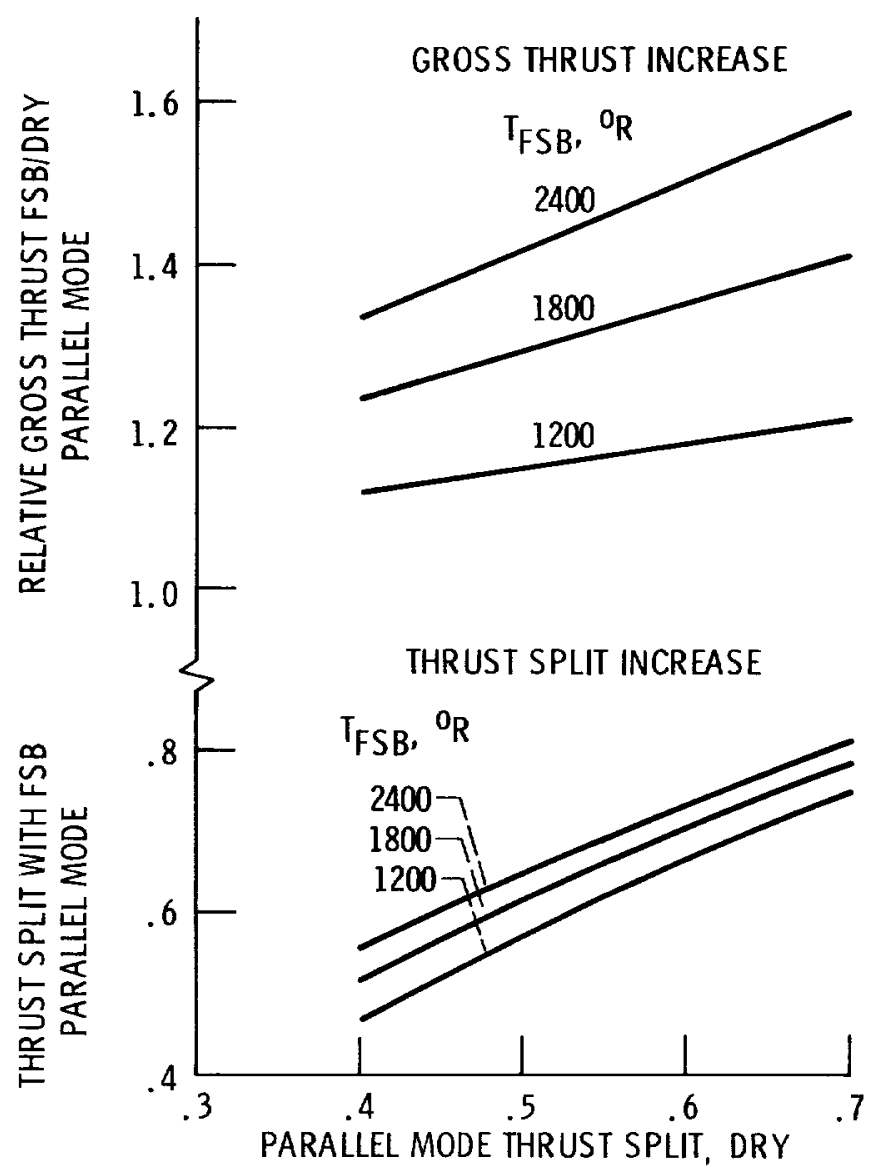

Figure 11. - Effect of fan stream burning (FSB) on gross thrust and thrust split of SPTF engines in parallel flow mode.

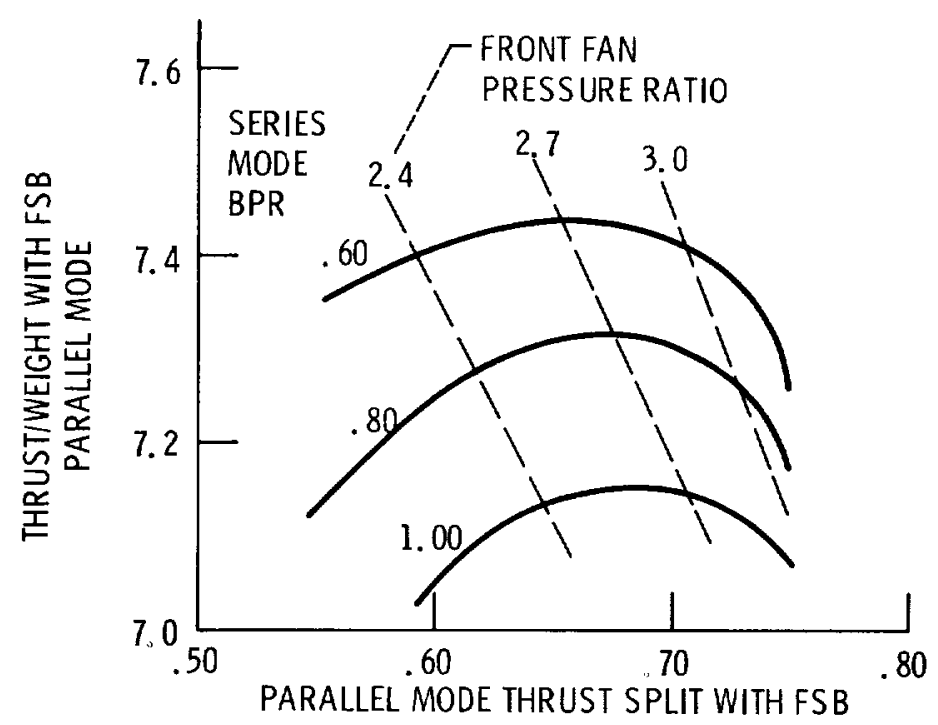

Figure 12. - Effect of fan stream burning (FSB) on bare engine thrust/weight for SPTF engines; fan stream augmentor temperature of $1800^{\circ} \mathrm{R}$. 


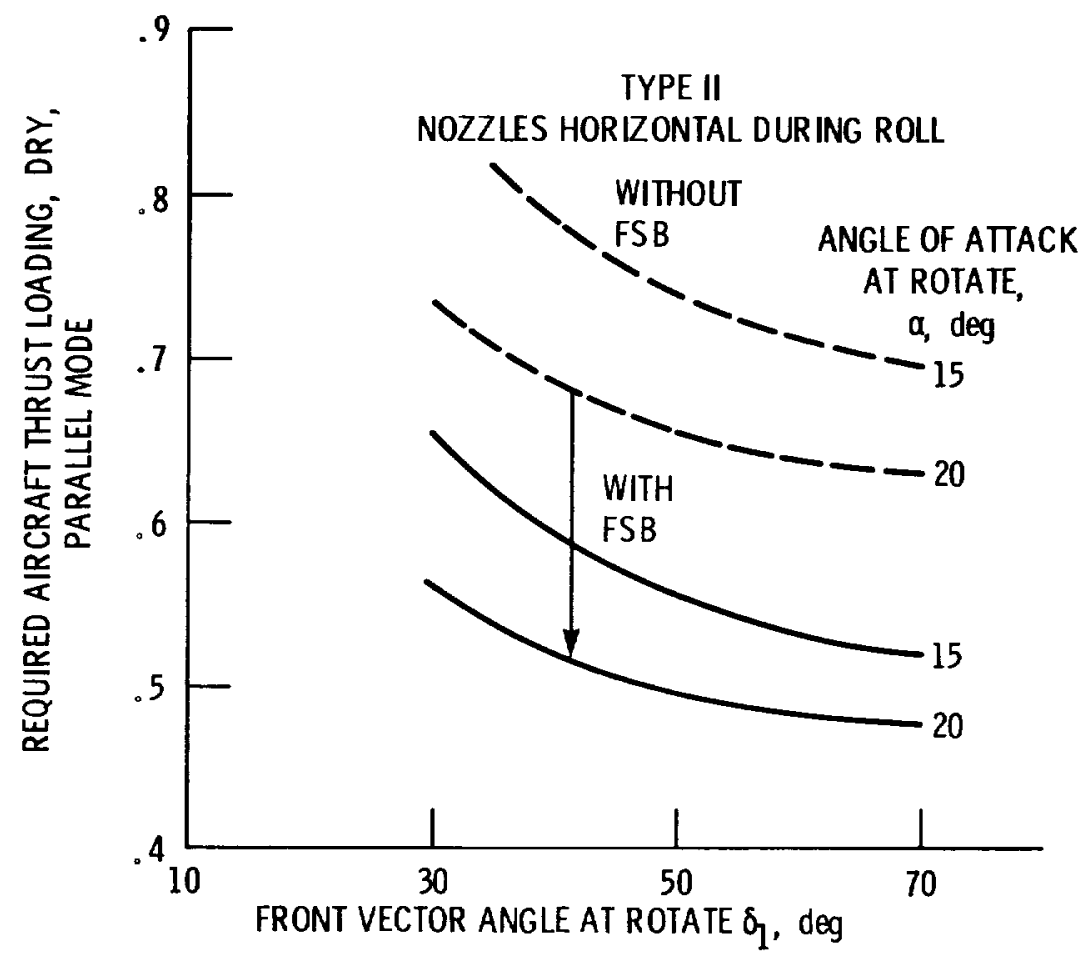

Figure 13. - Effect of fan stream burning (FSB) on vectored th rust short takeoff for typical fighter-type aircraft with SPTF engine; thrust split of 0.6 (with FSB); ground run of $400 \mathrm{ft}$; rear nozzle afterburner on.

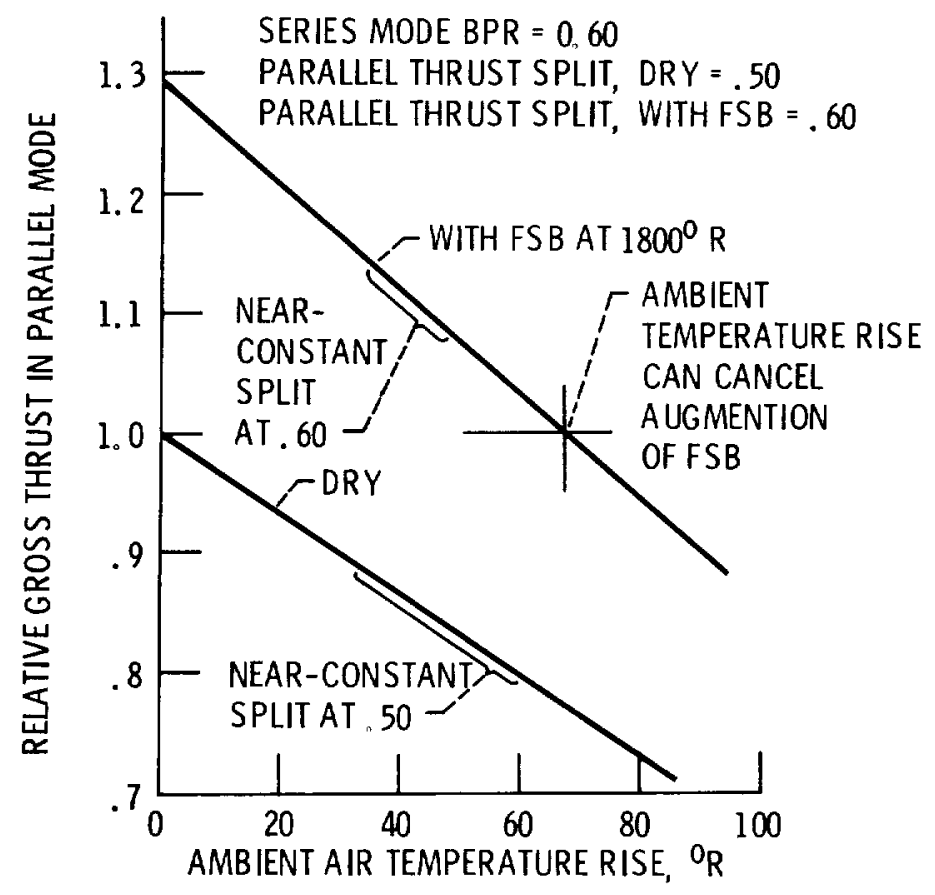

Figure 14. - Thrust reduction due to a mbient temperature rise, typical SPTF engine in parallel mode $w$ with and without fan stream burning, sea level static operation. 


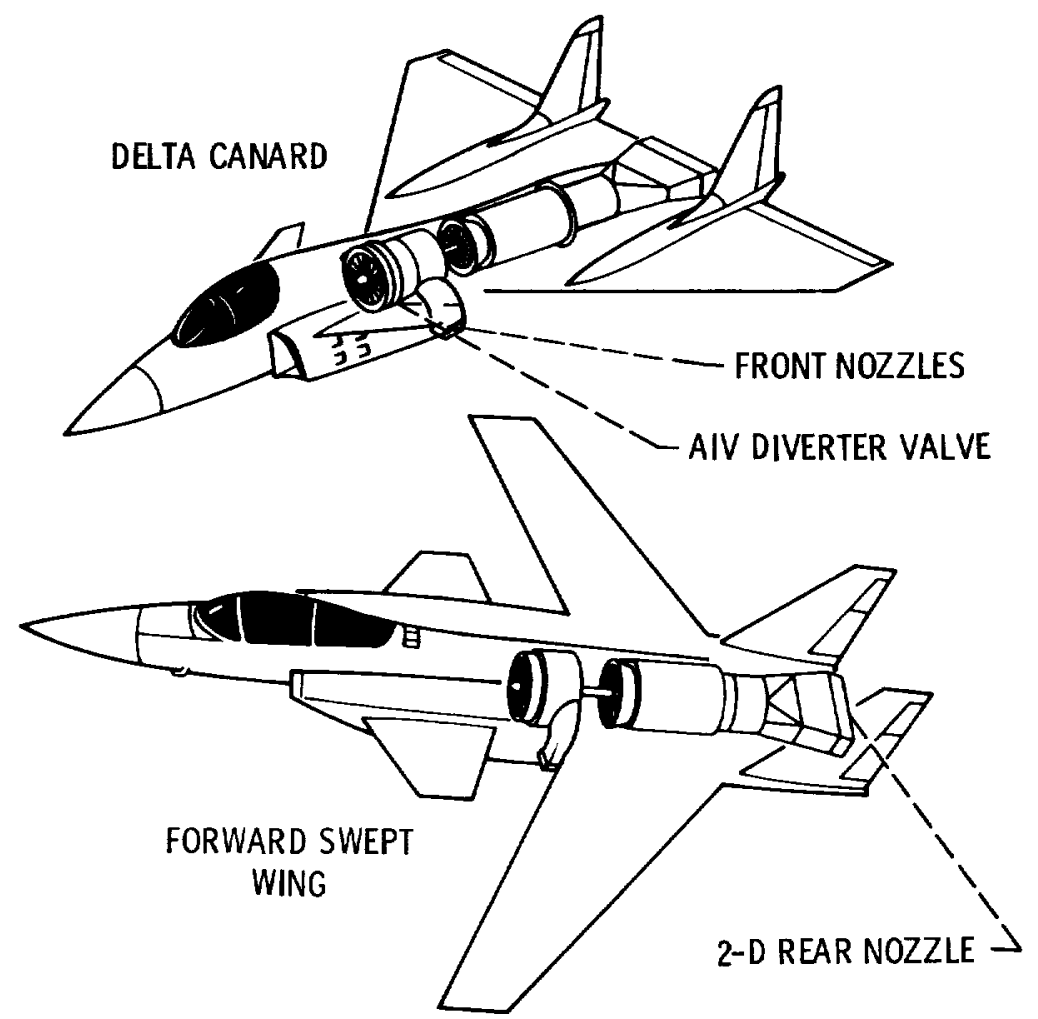

Figure 15. - Series/Parallel Tandem Fan propulsion systems in advanced STOVL fighter aircraft 


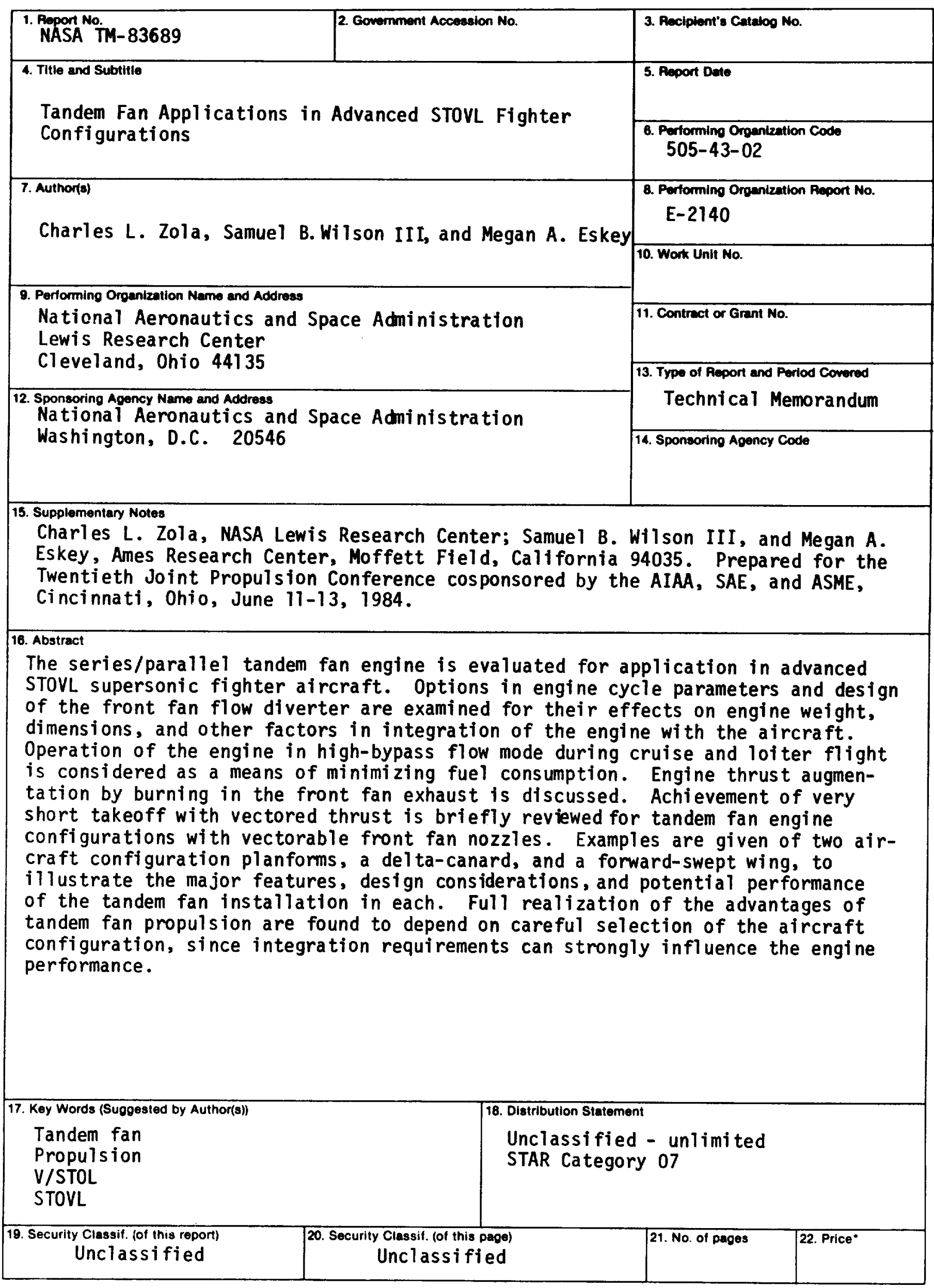

"For sale by the National Technical Information Service. Springfield, Virginia 22161 